
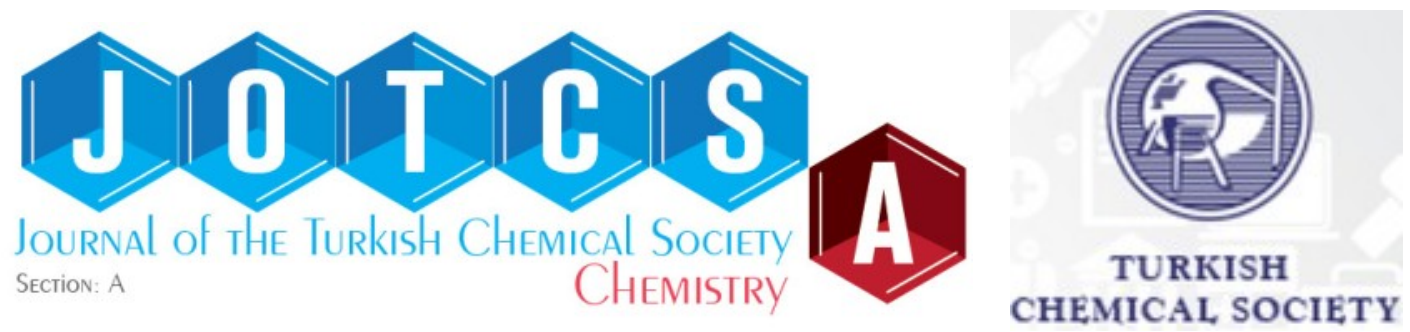

\title{
Synthesis and Characterization of Some New 4-Methyl-5-Imidazole Carbaldehyde Derivatives
}

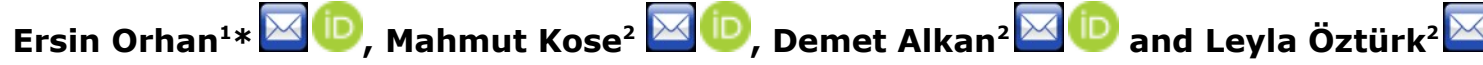 \\ ${ }^{1}$ Department of Chemistry, Faculty of Arts and Science, Düzce University, 81620, Düzce, Turkey. \\ ${ }^{2}$ Department of Chemistry, Faculty of Arts and Science, Bülent Ecevit University, 67100, Zonguldak, \\ Turkey.
}

Abstract: Imidazole is a common and important heterocyclic fragment of many biologically important molecules. 5-imidazole-carbaldehydes containing mono- ( $\mathrm{N}-1$ ) methyl (or aryl) analogs are commonly used as building blocks in medical chemistry. In this study, starting from 4 -methyl- $1 \mathrm{H}$-imidazole-5carbaldehyde, the $\mathrm{N}-1$ atom of the imidazole ring is derived with different alkyl groups. In addition, both $\mathrm{N}$ atoms of the starting imidazole-carbaldehyde were methylated to give 5-carbaldehyde-1,3,4trimethyl-3-imidazolium salt. The salt which possess quite reactive carbaldehyde group could be used as a precursor for synthesis of other imidazolium derivatives. Furthermore, 4-methyl-5-imidazole carbaldehyde was converted into the benzoxazole, benzothiazole and benzoimidazole by a two-step reaction over the aldehyde group. These new compounds could display some biological activities.

Keywords: Imidazole, imidazolium derivatives, biologically active imidazole.

Submitted: January 22, 2019. Accepted: September 05, 2019.

Cite this: Orhan E, Kose M, Alkan D, Öztürk L. Synthesis and Characterization of Some New 4-Methyl5-Imidazole Carbaldehyde Derivatives. JOTCSA. 2019;6(3):373-82.

DOI: https://doi.org/10.18596/jotcsa.530757.

*Corresponding author. E-mail: ersinorhan@duzce.edu.tr.

\section{INTRODUCTION}

Imidazole ring is one of the most basic groups of biologically important compounds. Many biologically active compounds containing the imidazole ring have been synthesized. Imidazole derivatives are used for the development of antifungal, antibacterial, anticancer, and antimalarial drugs. Until now, many drug and drug candidate isomers, containing imidazole and mono-N-alkylated imidazole rings, have been synthesized. For example, ipronidazole is a drug developed as an anti-protozoal agent (1). Nimorazole, a heterocyclic $\mathrm{N}$-alkyl substituted compound, is an effective antimicrobial drug in parasites of the genus trichomonas, synthesized in 1970 (2). The imidazole derivative known under the trade name of moxnidazole is an antimicrobial drug acting with trichomonas parasites. 
Another imidazole derivative that is effective against the Trichomonas parasites is flunidazole (3-6). Imidazole derivatives also have been used in the development of drugs for the treatment of ulcers. For example, the imidazole derivative known as Cimetidine is a highly effective drug in the treatment of ulcers (7). Highly complex imidazole-based drugs containing the imidazole group have also been developed. For example, the imidazole derivative known as dazadrol, is used as an anti-depressant (8). The drug called cimicoxib, which exhibits anti-inflammatory properties, is also an imidazole derivative (9). The imidazole derivative, Cipralisant, synthesized in recent years, has been found to be effective in attention deficit syndrome on animal studies. This compound is probably thought to be good for Alzheimer's disease (10-12). Imidazolium derivatives have begun to work in recent years. James H. Davis, Jr. et al. synthesized the first biologically active ionic liquid crystalline imidazolium cation starting from miconazole which exhibit antifungal properties (13). Azami et al. have synthesized many 1,3-dialkyl imidazolium derivatives and some of these compounds have antibacterial properties (14). In another study, imidazolium derivatives containing long alkyl chains on the $\mathrm{N}$ atom were synthesized and these compounds were found to have quite good antimicrobial activity on gram-negative, gram-positive bacteria and fungi (15). Donald D. Ourth et al. isolated and elucidated its structure of 1,3methylimidazolium derivatives which occurred naturally; this compound showed a broadspectrum antiviral properties for insects. This compound also contemplated that can be used in HIV-1 and HSV viruses seen in humans (1618). Jadwiga Zabielska-Matejuk et al. have synthesized several 1,3-dialkyimidazolium derivatives and studied their antifungal properties to protect wood materials. The synthesized imidazolium salts have been found to inhibit the growth of fungus, in particular Sclerophoma pityophila (19-27).

5-Imidazole-carbaldehyde and its mono- ( $\mathrm{N}-1)$ alkyl or aryl analogs are often used in medicine as drug building blocks, but their dialkyl ( $\mathrm{N}-1$ and $\mathrm{N}-3$ ) analogs are less visible in the literature. In this work, new imidazole derivatives were synthesized from 4-methyl-5imidazole carbaldehyde by alkylation of $\mathrm{N}$ atom or condensation of carbonyl group with appropriate reagents.

\section{EXPERIMENTAL}

\section{General}

The starting chemicals were commercially purchased from Merck, Aldrich, Acros Organics, and $A B C R$.

The ${ }^{1} \mathrm{H}$ NMR spectra were recorded on Bruker $400 \mathrm{MHz}$ spectrometers for samples in DMSO and $\mathrm{CDCl}_{3}$. The signals are expressed as parts per million down fields from $\left(\mathrm{CH}_{3}\right)_{4} \mathrm{Si}$, used as an internal standard. IR spectra were measured using a Jasco FT-IR-300E spectrometer. Electrospray ionization mass spectra were obtained in positive ion mode on a AB SCIEX LC - MS/MS spectrometer. Column chromatographic isolation was performed on Merck Kieselgel 60 (70-230 mesh) using ethyl acetate and n-hexane as the eluent. An analytical thin-layer chromatography was performed on Merck pre-coated silica gel 60 GF-254 with $0.25-\mathrm{mm}$ thick TLC plates.

\section{1,4-dimethyl-imidazole-5-carbaldehyde (1)}

$\mathrm{NaH}(60 \%, 2.179 \mathrm{~g}, 0.0908 \mathrm{~mol})$ in dry THF (120 mL) was added to 4-methyl-5-imidazole carbaldehyde ( $5 \mathrm{~g}, 0.0454 \mathrm{~mol}$ ) at room temperature for $30 \mathrm{~min}$. Methyl iodide (5.65 $\mathrm{mL}, 0.0908 \mathrm{~mol}$ ) was then added and mixed at room temperature for 20 hours. As a result of the reaction, the mixture had solid and liquid phases. The THF phase was isolated, then the solid phase was washed several times with $\mathrm{CHCl}_{3}$, then the organic phases were combined. The remaining precipitate was dissolved in water and extracted again with $\mathrm{CHCl}_{3}$. Then all the organic phases were combined and the solvent was evaporated. The resulting brownish-yellow oily substance was purified by column chromatography using ethyl acetate over silica gel. Isomer $\mathbf{1}$ was obtained as a yellow oily solid (3.32 g, 59\%). ${ }^{1} \mathrm{H}$ NMR (400 $\mathrm{MHz}, \mathrm{DMSO}): \mathrm{d}_{\mathrm{H}} 2.46\left(3 \mathrm{H}, \mathrm{s}, \mathrm{CH}_{3}\right), 3.60(3 \mathrm{H}, \mathrm{s}$, $\left.\mathrm{CH}_{3}\right), 7.73(1 \mathrm{H}, \mathrm{s}$, imidazole $\mathrm{C}-\mathrm{H}), 9.76(1 \mathrm{H}, \mathrm{s}$, $\mathrm{CHO})$.

\section{1-Benzyl-4-methyl-imidazole-5-carbaldehyde}

(2)

4-Methyl-5-imidazole carbaldehyde $(1 \mathrm{~g}, 9.08$ $\mathrm{mmol})$ was treated with $\mathrm{NaH}(60 \%, 720 \mathrm{mg}$, $18.16 \mathrm{mmol})$ in dry DMF $(120 \mathrm{~mL})$ at room temperature for $5 \mathrm{~min}$. Benzyl chloride (1.36 
$\mathrm{mL}, 11.8 \mathrm{mmol}$ ) was then added and mixed at room temperature for $20 \mathrm{~h}$. After that saturated sodium carbonate solution $(25 \mathrm{~mL})$ was added to the mixture, extracted by addition of $30 \mathrm{~mL}$ of water and extraction with ethyl acetate $(3 \times 30 \mathrm{~mL})$. The combined extracts were filtered after being dried over sodium sulfate. The solvent was removed on the rotary evaporator. The resulting brownishyellow oily substance was purified by column chromatography using ethyl acetate over silica gel. Yellow oily solid $(0.76 \mathrm{~g}, 42 \%)$. Mixture of isomers $\mathbf{2 a}$ and $\mathbf{2 b}{ }^{1} \mathrm{H}$ NMR $\left(400 \mathrm{MHz}, \mathrm{CDCl}_{3}\right)$ : $\mathrm{d}_{\mathrm{H}} 2.30\left(3 \mathrm{H}, \mathrm{s}, \mathrm{CH}_{3}\right), 2.38\left(3 \mathrm{H}, \mathrm{s}, \mathrm{CH}_{3}\right), 4.41$ $\left(2 \mathrm{H}, \mathrm{s}, \mathrm{N}-\mathrm{CH}_{2}\right), 4.67\left(2 \mathrm{H}, \mathrm{s}, \mathrm{N}-\mathrm{CH}_{2}\right), 7.30-7.62$ $(10 \mathrm{H}, \mathrm{m}, \mathrm{Ar}-\mathrm{H}), 9.79(1 \mathrm{H}, \mathrm{s}, \mathrm{CHO}), 9.83(1 \mathrm{H}$, $\mathrm{S}, \mathrm{CHO})$.

\section{1-(2-phenylethyl)-4-methyl-imidazole-5- carbaldehyde (3)}

4-Methyl-5-imidazole carbaldehyde $(0.5 \mathrm{~g}, 4.5$ $\mathrm{mmol}$ ) was treated with $\mathrm{NaH}(60 \%, 220 \mathrm{mg}$, $5.5 \mathrm{mmol})$ in dry DMF $(120 \mathrm{~mL})$ at room temperature for $5 \mathrm{~min}$. It was allowed to mix. 2-Phenylethylbromide $(0.7 \mathrm{~mL}, 5 \mathrm{mmol})$ was then added and mixed at room temperature for $20 \mathrm{~h}$. Saturated sodium carbonate solution (25 $\mathrm{mL}$ ) was then added to the mixture, extracted by addition of $25 \mathrm{~mL}$ of water and extraction with ethyl acetate $(2 \times \mathrm{V})$. The combined extracts were filtered after being dried over sodium sulfate. The solvent was removed on the rotary evaporator. The resulting brownishyellow oily substance was purified by column chromatography eluting with ethyl acetate over silica gel. It was seen from the ${ }^{1} \mathrm{H}$ NMR spectrum that this compound was an isomeric mixture in approximately equal proportions. Yellow oily solid $(0.48 \mathrm{~g}, 49 \%)$. Mixture of isomers $\mathbf{3 a}$ and $\mathbf{3} \mathbf{b}{ }^{1} \mathrm{H}$ NMR $\left(400 \mathrm{MHz}, \mathrm{CDCl}_{3}\right)$ : $\mathrm{d}_{\mathrm{H}} 2.27\left(3 \mathrm{H}, \mathrm{s}, \mathrm{CH}_{3}\right), 2.41\left(3 \mathrm{H}, \mathrm{s}, \mathrm{CH}_{3}\right), 2.93$ $\left(2 \times 2 \mathrm{H}, \mathrm{t}, 2 \times \mathrm{CH}_{2}\right), 4.05\left(2 \mathrm{H}, \mathrm{t}, \mathrm{N}-\mathrm{CH}_{2}\right), 4.40(2 \mathrm{H}$, $\left.\mathrm{t}, \mathrm{N}-\mathrm{CH}_{2}\right), 6.94-7.25(10 \mathrm{H}, \mathrm{m}, \mathrm{Ar}-\mathrm{H}), 9.82(1 \mathrm{H}$, $\mathrm{s}, \mathrm{CHO}), 9.85(1 \mathrm{H}, \mathrm{s}, \mathrm{CHO})$. IR (ATR, v/ $\left.\mathrm{cm}^{-1}\right)$ : 3127, 2923-2852, 1662, 1610. ESI-MS: $\mathrm{m} / \mathrm{z}=$ $215(\mathbf{M})^{+}$; Calcd. for $\mathrm{C}_{13} \mathrm{H}_{14} \mathrm{~N}_{2} \mathrm{O}: 214.11$.

\section{1-(2-Chlorobenzyl)-4-methyl-imidazole-5- carbaldehyde (4)}

4-Methyl-5-imidazole carbaldehyde (1 g, 9 $\mathrm{mmol})$ was treated with $\mathrm{NaH}(60 \%, 720 \mathrm{mg}$, $18 \mathrm{mmol})$ in dry DMF $(120 \mathrm{~mL})$ at room temperature for $5 \mathrm{~min}$. It was allowed to $\mathrm{mix}$. 2-chlorobenzyl bromide (1.53 mL, $10 \mathrm{mmol}$ ) was then added and mixed at room temperature for 1 day. Saturated sodium carbonate solution $(25 \mathrm{~mL})$ was then added to the mixture extracted by the addition of about 25-30 mL of water and extraction with ethyl acetate $(3 \times 40 \mathrm{~mL})$. The combined extracts were filtered after being dried over sodium sulfate. The solvent was removed on the rotary evaporator. The resulting brown-yellow oily substance was purified by column chromatography eluting with ethyl acetate over silica gel. Yellow oily solid was observed as a mixture of products in ${ }^{1} \mathrm{H}$ NMR $(0.82 \mathrm{~g}, 39 \%)$. Main product 4a (\%85): ${ }^{1} \mathrm{H}$ NMR $(400 \mathrm{MHz}$, $\left.\mathrm{CDCl}_{3}\right): \mathrm{d}_{\mathrm{H}} 2.42\left(3 \mathrm{H}, \mathrm{s}, \mathrm{CH}_{3}\right), 5.48\left(2 \mathrm{H}, \mathrm{s}, \mathrm{CH}_{2}\right)$, 6.90-7.48 (5H, m, Ar-H), $9.73(1 \mathrm{H}, \mathrm{s}, \mathrm{CHO})$.

By-product 4b (\%15): ${ }^{1} \mathrm{H}$ NMR $(400 \mathrm{MHz}$, $\left.\mathrm{CDCl}_{3}\right): \mathrm{d}_{\mathrm{H}} 2.37\left(3 \mathrm{H}, \mathrm{s}, \mathrm{CH}_{3}\right), 4.66\left(2 \mathrm{H}, \mathrm{s}, \mathrm{CH}_{2}\right)$, 6.90-7.48 (5H, m, Ar-H), $9.85(1 \mathrm{H}, \mathrm{s}, \mathrm{CHO}) . \mathrm{IR}$ $\left(A T R, v / \mathrm{cm}^{-1}\right): 3111,2851,1661,1543$. ESIMS : $\mathrm{m} / \mathrm{z}=235(\mathbf{M})^{+} ;$Calc. for $\mathrm{C}_{12} \mathrm{H}_{11} \mathrm{ClN}_{2} \mathrm{O}: 234.05$.

1-(3-Chlorobenzyl)-4-methyl-imidazole-5carbaldehyde (5)

4-Methyl-5-imidazole carbaldehyde (1 g, 9 $\mathrm{mmol})$ was treated with $\mathrm{NaH}(60 \%, 720 \mathrm{mg}$, $18 \mathrm{mmol})$ in dry DMF $(120 \mathrm{~mL})$ at room temperature for $5 \mathrm{~min}$. It was allowed to mix. 3-Chlorobenzyl bromide $(1.4 \mathrm{~mL}, 10 \mathrm{mmol})$ was then added and mixed at room temperature for 1 day. Saturated sodium carbonate solution $(25 \mathrm{~mL})$ was then added to the mixture extracted by addition of $25 \mathrm{~mL}$ of water and extraction with ethyl acetate $(3 \times 40$ $\mathrm{mL}$ ). The combined extracts were filtered after being dried over sodium sulfate. Solvent was removed on the rotary evaporator. The resulting oily substance was purified by column chromatography eluting with ethyl acetate over silica gel. Yellow oily solid $(0.71 \mathrm{~g}, 33 \%)$. It was found from the ${ }^{1} \mathrm{H}$ NMR results that the material was isolated as an isomeric mixture.

Main product 5a (\%71): ${ }^{1} \mathrm{H}$ NMR $(400 \mathrm{MHz}$, $\left.\mathrm{CDCl}_{3}\right): \mathrm{d}_{\mathrm{H}} 2.43\left(3 \mathrm{H}, \mathrm{s}, \mathrm{CH}_{3}\right), 5.36\left(2 \mathrm{H}, \mathrm{s}, \mathrm{CH}_{2}\right)$, 6.98-7.54 (5H, m, Ar-H), $9.74(1 \mathrm{H}, \mathrm{s}, \mathrm{CHO})$. By-product 5b (\%29): ${ }^{1} \mathrm{H}$ NMR $(400 \mathrm{MHz}$, $\left.\mathrm{CDCl}_{3}\right): \mathrm{d}_{\mathrm{H}} 2.34\left(3 \mathrm{H}, \mathrm{s}, \mathrm{CH}_{3}\right), 4.95\left(2 \mathrm{H}, \mathrm{s}, \mathrm{CH}_{2}\right)$, 6.98-7.54 (5H, m, Ar-H), $9.88(1 \mathrm{H}, \mathrm{s}, \mathrm{CHO})$. IR $\left(\right.$ ATR, v/cm ${ }^{-1}$ ): 3088, 2936, 2841, 1659, 1598. ESI-MS : $\mathrm{m} / \mathrm{z}=235(\mathbf{M})^{+}$; Calc. for $\mathrm{C}_{12} \mathrm{H}_{11} \mathrm{ClN}_{2} \mathrm{O}: 234.05$. 
5-formyl-1,3,4-trimethyl-imidazolium tetrafluoroborate (6)

1,4-dimethyl-1H-imidazole-5-carbaldehyde (1 $\mathrm{g}, \quad 8.77 \mathrm{mmol}$ ) and trimethyloxonium tetrafluoroborate $(1.55 \mathrm{~g}, 0.0105 \mathrm{~mol})$ were stirred in dry ethyl acetate $(15 \mathrm{~mL})$ for 2 hours at room temperature. The solvent was removed on the rotary evaporator. Due to the fact that the product is highly polar, the organic phase could not be extracted and also could not be purified by chromatography. The mixture was further left to rinse in a mixture of ethanol and chloroform. ${ }^{1} \mathrm{H}$ NMR analysis was performed on pure white crystals and the expected product was observed to be formed. ${ }^{1} \mathrm{H}$ NMR (400 MHz, DMSO): $\mathrm{d}_{\mathrm{H}} 2.59(3 \mathrm{H}, \mathrm{s}$, $\left.\mathrm{CH}_{3}\right), 3.79\left(3 \mathrm{H}, \mathrm{s}, \mathrm{N}-\mathrm{CH}_{3}\right), 4.00\left(3 \mathrm{H}, \mathrm{s}, \mathrm{N}-\mathrm{CH}_{3}\right)$, $9.14(1 \mathrm{H}, \mathrm{S}$, imidazolium $\mathrm{C}-\mathrm{H}), 9.94(1 \mathrm{H}, \mathrm{S}$, $\mathrm{CHO})$.

\section{2-((4-methyl-1H-imidazole-5-}

yl)methyleneamino)phenol (8)

4-methyl-1H-imidazole-5-carbaldehyde (1 g, $9.082 \mathrm{mmol}), 2$-aminophenol (0.99 g, 9.082 $\mathrm{mmol}$ ) was refluxed in $95 \% \mathrm{EtOH}$ for 1 day. The reaction mixture was allowed to crystallize with EtOH. A light yellow solid 4.3.1 (0.81 g, $44 \%$ ) was obtained. Compound 8 was found to have very little impurity from the ${ }^{1} \mathrm{H}$ NMR spectrum. ${ }^{1} \mathrm{H}$ NMR (400 $\mathrm{MHz}$, DMSO): $\mathrm{d}_{\mathrm{H}} 2.38$ $\left(3 \mathrm{H}, \mathrm{s}, \mathrm{CH}_{3}\right), 6.8-7.07(4 \mathrm{H}, \mathrm{m}, \mathrm{Ar}-\mathrm{H}), 7.45(1 \mathrm{H}$, $\mathrm{S}, \mathrm{N}=\mathrm{C}-\mathrm{H}), 7.83(1 \mathrm{H}, \mathrm{S}$, imidazole $\mathrm{C}-\mathrm{H}), 8.73$ $(1 \mathrm{H}, \mathrm{s}, \mathrm{Ar}-\mathrm{OH}), 12.61(1 \mathrm{H}$, broad $\mathrm{s}, \mathrm{N}-\mathrm{H})$.

\section{2-((4-methyl-1H-imidazole-5-}

yl)methyleneamino)benzenethiol (9)

4-Methyl-5-imidazole carbaldehyde $(1 \mathrm{~g}, 9.082$ $\mathrm{mmol})$ and 2-aminothiophenol (1.137 g, 9.082 $\mathrm{mmol})$ were refluxed in EtOH $(20 \mathrm{~mL})$ for 1 hour. The reaction was followed by TLC (50\% EtOAc / n-Hexane) .The reaction was continued until the starting material was finished in the TLC. When the reaction mixture was allowed to cool, it was immediately observed that light cream crystals began to form. A quantity of the obtained solid light cream matter (1.494 g) was observed to be $\mathbf{1 2}$ by $1 \mathrm{H}$ NMR analysis 9 as well as part of the material being converted to ring closure reaction. It was detected from the ${ }^{1} \mathrm{H}$ NMR spectrum that the ratio of $\mathbf{9}$ to $\mathbf{1 2}$ was $79: 21$.

Main product 9 (\%79): ${ }^{1} \mathrm{H}$ NMR (400 $\mathrm{MHz}$, DMSO): $d_{H} 2.16\left(3 \mathrm{H}, \mathrm{s}, \mathrm{CH}_{3}\right), 3.38(1 \mathrm{H}, \mathrm{s}, \mathrm{SH})$, 6.48-6.59 $(3 \mathrm{H}, \mathrm{m}, \mathrm{Ar}-\mathrm{H}), 6.61-6.97(2 \mathrm{H}, \mathrm{m}$,
Ar-H), $7.45(1 \mathrm{H}, \mathrm{s}$, imidazole $\mathrm{C}-\mathrm{H}), 8.02(1 \mathrm{H}$, $\mathrm{S}, \mathrm{N}=\mathrm{C}-\mathrm{H}), 11.93(1 \mathrm{H}$, broad $\mathrm{S}, \mathrm{N}-\mathrm{H})$.

By-product 12 (\%21): ${ }^{1} \mathrm{H}$ NMR (400 MHz, DMSO): $d_{H} 2.66\left(3 \mathrm{H}, \mathrm{s}, \mathrm{CH}_{3}\right), 7.34-7.48(2 \mathrm{H}$, d.t., $2 x \mathrm{Ar}-\mathrm{H}), 7.70(1 \mathrm{H}, \mathrm{s}$, imidazole $\mathrm{C}-\mathrm{H})$, 7.90- $8.04(2 \mathrm{H}$, d.d., 2xAr-H), $12.56(1 \mathrm{H}$, broad $\mathrm{s}, \mathrm{N}-\mathrm{H})$.

2-((4-methyl-1H-imidazole-5yl)methyleneamino)aniline (10)

1-2-diaminobenzene (1.178 $\mathrm{g}, 10.9 \mathrm{mmol})$ with 4-methyl-5-imidazolecarbaldehyde (1 g, $9.082 \mathrm{mmol}$ ) was refluxed in $20 \mathrm{~mL} \mathrm{EtOH}$ for 1 day. The reaction was extracted by TLC (20\% EtOH, EtOAc), the product was observed to be lower in TLC as it was more polar than imidazole. The solvent was removed and the remaining mixture was purified by flash column chromatography on silica gel using n-hexane, ethyl acetate and EtOH. (The solvent polarity for the separation was $20 \%$ acetate-n-hexane and the temperature was increased to $50 \%$ EtOH / EtOAc mixture). The fractions of the product were collected and the solvent was removed to give the target compound $\mathbf{1 0}$ as a light brown solid (1.66 g, 90\%).

It was determined that there is an isomeric mixture of $\mathbf{1 0}$ from ${ }^{1} \mathrm{H}$ NMR spectrum. The isomeric mixture may possibly be an $E / Z$ mixture around $-\mathrm{N}=\mathrm{CH}-$. The isomeric ratios were found to be $63 \%$ for the main isomer and $37 \%$ for the other isomer. ${ }^{1} \mathrm{H}$ NMR $(400 \mathrm{MHz}$, DMSO): $\mathrm{d}_{\mathrm{H}} 2.56\left(3 \mathrm{H}, \mathrm{s}, \mathrm{CH}_{3}\right), 2.65(3 \mathrm{H}, \mathrm{s}$, $\left.\mathrm{CH}_{3}\right), 7.10-7.59(8 \mathrm{H}, \mathrm{m}, \mathrm{Ar}-\mathrm{H}), 7.48(1 \mathrm{H}, \mathrm{s}$, imidazole $\mathrm{C}-\mathrm{H}), 7.71(1 \mathrm{H}, \mathrm{s}$, imidazole $\mathrm{C}-\mathrm{H})$, $7.82(2 \mathrm{H}, \mathrm{s}, \mathrm{N}=\mathrm{C}-\mathrm{H}), 12.25(2 \mathrm{H}$, broad $\mathrm{s}, \mathrm{N}-\mathrm{H})$.

2-(4-methyl-1H-imidazole-5-

yl)benzo[d]oxazole (11)

2-((4-methyl-1H-imidazol-5-

yl)methyleneamino)phenol (8) (0.6 g, 2.28 $\mathrm{mmol})$ and lead tetraacetate $(1.32 \mathrm{~g}, 2.98$ $\mathrm{mmol})$ were dissolved in acetic acid $(12 \mathrm{~mL})$ at 45-50 ${ }^{\circ} \mathrm{C}$ for 24 hours. The reaction was monitored by TLC (25\% EtOH / EtOAc); TLC was observed to walk faster because it is less polar than the starting material of the product. The reaction mixture was basified in ice bath with about $20 \mathrm{~mL}$ of $10 \% \mathrm{NaOH}$. The organic extracts were extracted with chloroform and the organic phase was dried over sodium sulfate. The mixture was separated by column chromatography on silica gel using n-hexane, 
ethyl acetate, and EtOH. (The solvent polarity for the separation was $5 \%$ ethyl acetate-nhexane and eluted to $25 \% \mathrm{EtOH} /$ EtOAc mixture). Compound $\mathbf{1 1}$ was isolated as a pale yellow solid $(0.41 \mathrm{~g}, 69 \%) .{ }^{1} \mathrm{H}$ NMR $(400 \mathrm{MHz}$, DMSO): $\mathrm{d}_{\mathrm{H}} 2.63\left(3 \mathrm{H}, \mathrm{s}, \mathrm{CH}_{3}\right), 7.35(2 \mathrm{H}, \mathrm{m}$, 2xAr-H), $7.72(2 \mathrm{H}, \mathrm{m}, 2 \times \mathrm{Ar}-\mathrm{H}), 7.83(1 \mathrm{H}, \mathrm{s}$, imidazole $\mathrm{C}-\mathrm{H})$. IR $\left(\mathrm{ATR}, \mathrm{v} / \mathrm{cm}^{-1}\right)$ : 3379, 1642. ESI-MS : $\mathrm{m} / \mathrm{z}=200(\mathbf{M})^{+}$; Calcd. for $\mathrm{C}_{11} \mathrm{H}_{9} \mathrm{~N}_{3} \mathrm{O}: 199.07$.

\section{2-(4-methyl-1H-imidazole-5-}

yl)benzo[d]thiazole (12)

Compound $9(0.6 \mathrm{~g}, 2.764 \mathrm{mmol})$ and lead tetraacetate $(1.2 \mathrm{~g}, 2.764 \mathrm{mmol})$ were stirred in acetic acid $(10 \mathrm{~mL})$ at $45-50{ }^{\circ} \mathrm{C}$ for 1 day. After termination of the reaction, the mixture was basified in ice bath with about $20 \mathrm{~mL}$ of $\mathrm{NaOH}$. The organic material was extracted with chloroform and the organic phase was dried over sodium sulfate. The solvent was removed and the residue was chromatographed on silica gel in a mixture of ethyl acetate-n-hexane (1: 1). Compound $\mathbf{1 2}$ was obtained as a yellow solid $(0.348 \mathrm{~g}, 30 \%) .{ }^{1} \mathrm{H}$ NMR $(400 \mathrm{MHz}$, DMSO): $d_{H} 2.66\left(3 \mathrm{H}, \mathrm{s}, \mathrm{CH}_{3}\right), 7.33-7.48(2 \mathrm{H}$, d.t., $2 \times A r-H), 7.71(1 \mathrm{H}, \mathrm{s}$, imidazole $\mathrm{C}-\mathrm{H})$, 7.91- $8.05(2 \mathrm{H}$, d.d., 2xAr-H), $12.58(1 \mathrm{H}$, broad S, N-H). IR (ATR, v/cm $\left.{ }^{-1}\right): 3054,3015$, 2937-2838-2711, 1603. ESI-MS : $\mathrm{m} / \mathrm{z}=$ $216(\mathbf{M})^{+}$; Calc. for $\mathrm{C}_{11} \mathrm{H}_{9} \mathrm{~N}_{3} \mathrm{~S}: 215.05$.
2-(4-methyl-1H-imidazole-5-yI)-1Hbenzimidazole (13)

2-((4-methyl-1H-imidazole-5-

yl)methyleneamino)aniline (10) (1.1281 g, $5.63 \mathrm{mmol}$ ) and lead acetate $(2.49 \mathrm{~g}, 5.63$ $\mathrm{mol})$ in glacial acetic acid $(20 \mathrm{~mL})$ was added for 24 hours at $35-40{ }^{\circ} \mathrm{C}$. It was basified with $10 \% \mathrm{NaOH}$. Extraction with chloroform was performed. ( $3 x \mathrm{~V})$ and the organic phase was dried over sodium sulfate. Crystallization yielded 13 as a light yellow solid (0.66 g, $59 \%) .{ }^{1} \mathrm{H}$ NMR (400 MHz, DMSO): $\mathrm{d}_{\mathrm{H}} 2.55$ $\left(3 \mathrm{H}, \mathrm{s}, \mathrm{CH}_{3}\right), 7.14(2 \mathrm{H}, \mathrm{m}, 2 \mathrm{xAr}-\mathrm{H}), 7.39(1 \mathrm{H}$, $\mathrm{s}), 7.58(2 \mathrm{H}, \mathrm{m}, 2 \mathrm{xAr}-\mathrm{H}), 7.80(1 \mathrm{H}, \mathrm{s}$, imidazole $\mathrm{C}-\mathrm{H}), 12.45(1 \mathrm{H}$, broad $\mathrm{s}, \mathrm{N}-\mathrm{H})$.

IR (ATR, v/cm ${ }^{-1}$ ): 3127, 2922, 2852, 1606. ESI-MS : 293.1(M) ${ }^{+}$; Calc. for $\mathrm{C}_{11} \mathrm{H}_{10} \mathrm{~N}_{4}: 198.09$.

\section{RESULTS AND DISCUSSION}

The alkylation reaction of 4-methyl-5-imidazole carbaldehyde is shown in Figure 1 . The acidic $\mathrm{N}-\mathrm{H}$ hydrogen in the imidazole ring was first ionized with strong base $\mathrm{NaH}$ and then converted to the corresponding primary alkyl halides ( $\mathrm{N}$-alkylation) by reaction with the $\mathrm{S}_{\mathrm{N}} 2$ type reaction.

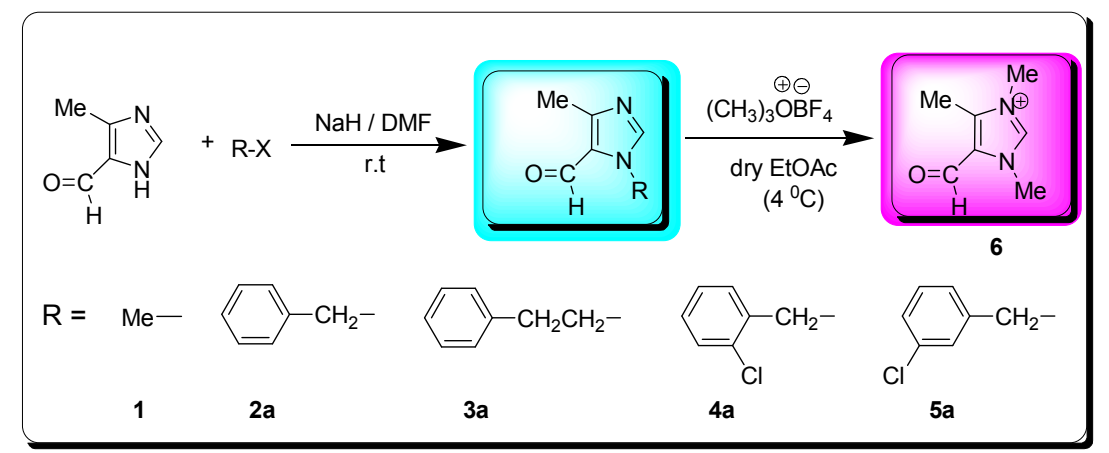

Figure 1. The alkylation reaction of 4-methyl-5-imidazole carbaldehyde.

An isomeric mixture or polyalkylation can be expected because of the presence of two $\mathrm{N}$ atoms on the imidazole ring. As a result of the reaction with $\mathrm{Me}-\mathrm{I}$, very pure $\mathrm{N}$-methylated imidazole derivative was obtained. ${ }^{1} \mathrm{H}-\mathrm{NMR}$ analyses showed that there was only one isomer $\mathbf{1}$ for this compound. In the Me-I reaction, although more than two equivalents of Me-I was taken, multiple alkylation has not been detected. 

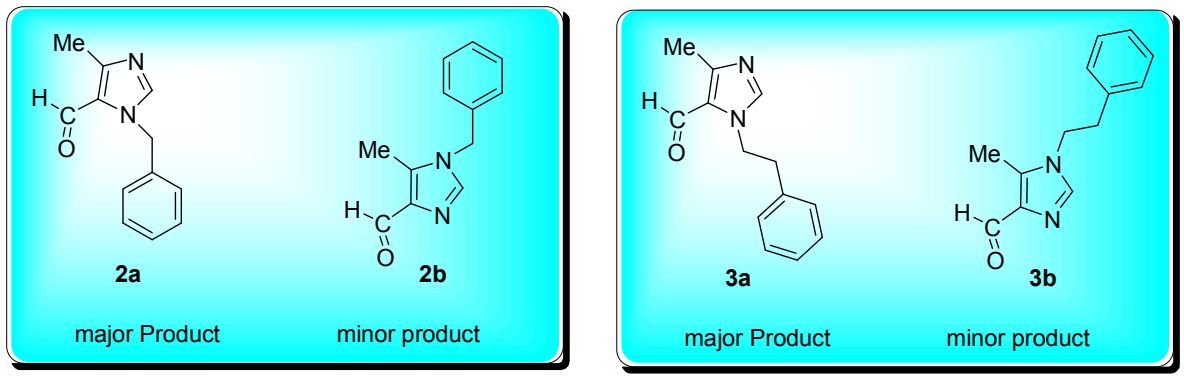

Figure 2. Isomeric mixtures of $\mathbf{2} \mathbf{a}, \mathbf{2} \mathbf{b}$ and $\mathbf{3 a}, \mathbf{3} \mathbf{b}$.

The second reaction of this section is the reaction with benzyl chloride $\left(\mathrm{PhCH}_{2} \mathrm{Cl}\right)$. Among the alkyl halides used, only benzyl chloride is less reactive than the others (other alkyl halides are alkyl bromides and iodides). From the benzyl chloride reaction, the product was impure and is also an isomeric mixture. However, when the alkylation reaction was carried out with sterically more hindered alkyl group, such as 2-phenylethyl bromide, isomeric mixture (3a and $\mathbf{3 b}$ ) were obtained (Figure 2). The ${ }^{1} \mathrm{H}-\mathrm{NMR}$ analysis showed that the isomeric mixture almost in the vicinity of 50:50. When alkylation reactions was carried out with 2chlorobenzyl bromide or 3-chlorobenzyl bromide, which are structurally very similar with benzyl chloride, the reaction proceeded smoothly and expected products (4a and $\mathbf{5 a}$ ) were obtained. In all alkylation reactions, except Me-I, the product was obtained both as a low yield and as an isomeric mixture; for instance, the alkylation reaction of 4-methyl-5- imidazole carbaldehyde with 2-chlorobenzyl bromide or 3-chlorobenzyl bromide gave about $30 \%$ yield and the products were isomeric mixture (4a / $\mathbf{4 b}$ and $\mathbf{5 a} / \mathbf{5 b}$ ). But from the similar reaction with Me-I, only one isomer with higher yield $(60 \%)$ was obtained.

The isomeric mixtures of $\mathbf{4 a}$ and $\mathbf{4 b}$ or $\mathbf{5 a}$ and 5b, could not be separated completely by column chromatography (Figure 3 ). ${ }^{1} \mathrm{H}$ NMR analysis indicated that the major isomer was $\mathbf{4 a}$ and the minor isomer was $\mathbf{4 b}$ and the ratio of the two isomers was $85: 15$. Similar way, the $\mathrm{H}$ NMR spectroscopy showed that the $\mathbf{5 a}$ is major and the $\mathbf{5 b}$ is minor and isomer ratio is $71 / 29$. It is not surprising that, although the isomeric mixture is not observed in the reaction with $\mathrm{MeI}$, the alkyl halides with a large $\mathrm{R}$ group causes isomerization. This can be attributed to the steric effect of the carbaldehyde group adjacent to the $\mathrm{N}-\mathrm{H}$ group.
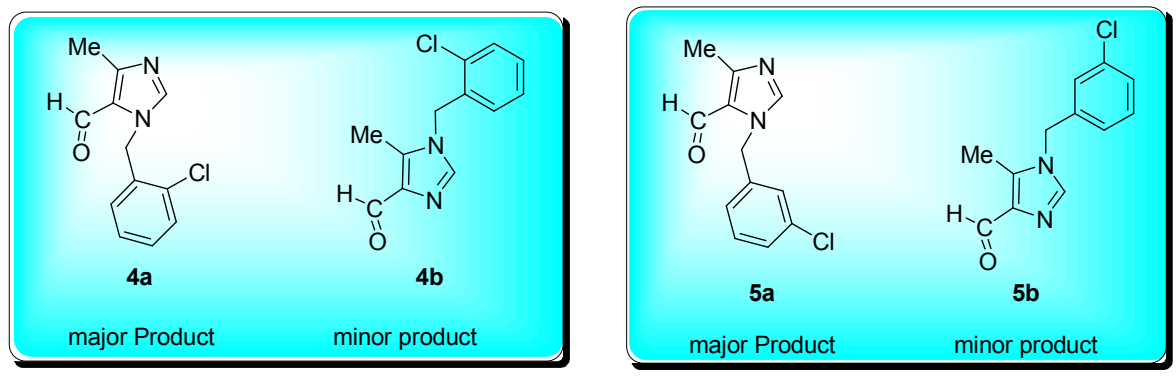

Figure 3. Isomeric mixtures of $\mathbf{4 a}, \mathbf{4 b}$ and $\mathbf{5 a}, \mathbf{5 b}$.

4-Methyl-5-imidazole carbaldehydes (N-R) were tried to convert to their imidazolium salts using $\left(\mathrm{CH}_{3}\right)_{3} \mathrm{O}^{+} \mathrm{BF}_{4}{ }^{-}$, from this reaction only $\mathrm{N}$ -
Me isomer $\mathbf{1}$ gave desired imidazolium salt $\mathbf{6}$, but other isomers (N-R) for example 5a could not converted to $\mathbf{7}$ (figure 4 ). 


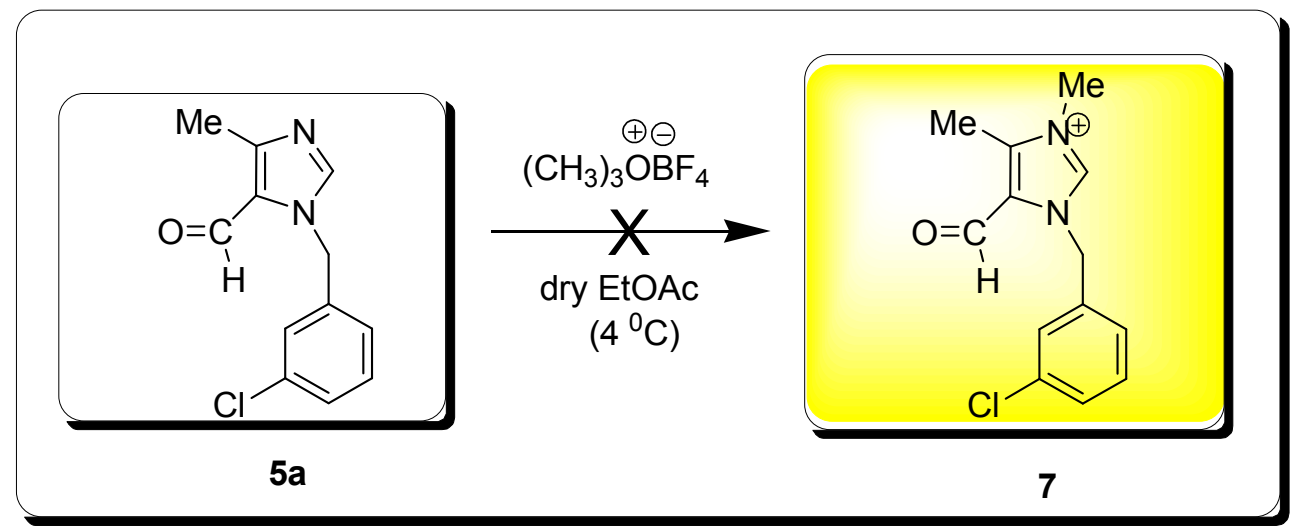

Figure 4. Unsuccessful synthesis of compound 7.

Synthesis of benzoxazole, benzothiazole and benzimidazole derivatives from 4methyl-5-imidazole carbaldehyde

In the literature, benzoxazole, benzothiazole and benzimidazole derivatives were synthesized from less reactive carbonyl compounds with 2-aminophenol, 2aminobenzenethiol and 1,2-diaminobenzene etc via two step Schiff base reaction and their antimicrobial effects were investigated (28-32). Therefore, it was thought that the basic starting material used in this study, 4-methyl5-imidazole carbaldehyde, could react with 2aminophenol, 2-aminobenzenethiol, and 1,2diaminobenzene. Thus, synthesis of benzoxazole, benzothiazole and benzimidazole derivatives containing imidazole rings has been tried to synthesize by a two-step reaction as shown in Figure 5 . The intermediate products (8, 9 and 10), obtained as a result of the first step shown in Figure 5, were isolated as an isomeric mixture or with some impurities (analyzed by ${ }^{1} \mathrm{H}$ NMR spectroscopy). The isomerization (cis / trans isomers) may be derived from the $-\mathrm{N}=\mathrm{CH}$ - double bond. Further reaction of the intermediates gave new benzoxazole, benzothiazole and benzimidazoles $(11,12$ and 13) as pure compounds.

In addition, compounds $1,2,12$ and 13 were synthesized by different methods from the literature (33-35). 


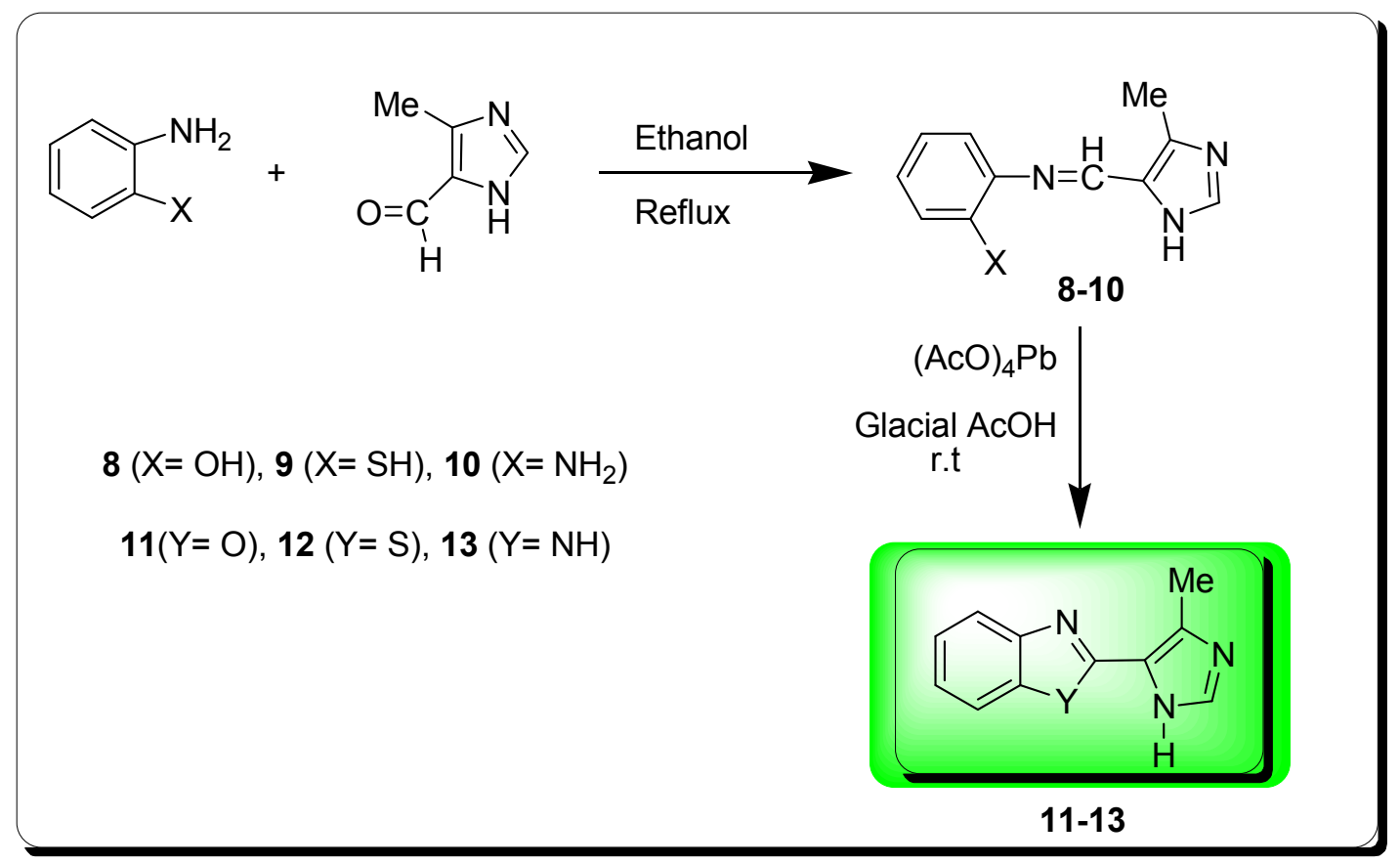

Figure 5. Synthesis of benzoxazole, benzothiazole and benzimidazole derivativescontaining imidazole ring.

\section{CONCLUSIONS}

In this work, the $\mathrm{N}-1$ atom on the imidazole ring of the starting 4-methyl-1H-imidazole-5carbaldehyde were derivatized with different alkyl groups. In addition, both $\mathrm{N}$ atoms of the starting imidazole-carbaldehyde were methylated to give 5-carbaldehyde-1,3,4trimethyl-3-imidazolium salt. The salt which possess quite reactive carbaldehyde group could be used for synthesis of other imidazolium derivatives. Furthermore, 4methyl-5-imidazole carbaldehyde was converted into the benzoxazole, benzothiazole and benzimidazoles by a two-step reaction over the aldehyde group. These new compounds could display some biological activities.

\section{ACKNOWLEDGMENTS}

The authors are grateful to the Zonguldak Bülent Ecevit University (Grant No.: BAP 201472118496-06) and Düzce University (Grant No.: 2012.05.03.097) for the financial aid of this study.

\section{REFERENCES}

1. Butler K, Howes HL, Lynch JE and Pirie DK. Nitroimidazole Derivatives. Relationship between Structure and Antitrichomonal Activity. J. Med. Chem. 1967;10(5):891-7.

2. a) Giraldi PN, Mariotti V, Namini G, Tosolini GP, Dradi E, Logemann W, de Carnevi I, Monti G. Arzneimittelforsch. 1970; 20,52 b) Heeres J, Mostmans JH and Maes R, German Patent, $1975 ; 2: 429,755$.

3. Rufer C, Kessler HJ, Schroeder E. Chemotherapeutic nitroheterocycles 6. Substituted 5- aminomethyl-3-(5-nitro-2imidazolylmethyleneamino)-2-oxazolidinones.

J. Med. Chem. 1971; 14(2):94-6.

4. Arton., Netherlands Patent, 1965, 6413814; Chem. Abstr., 1965, 63, 18097b

5. Godefroi EF, Van Cutsem J, Van Der Eycken CAM, Janssen PAJ. Med. Chem. 1967;10:1160. 
6. Godefroi EF, Heeres J, Van Cutsem J, Janssen PAJ. Preparation and antimycotic properties of derivatives of 1phenethylimidazole. J. Med. Chem. 1969;12 (5):784-91.

7. Durant GJ, Emmett JC, Ganellin CR, Miles $P D$, Parsons ME, Prain HD, White GR. Cyanoguanidine-thiourea equivalence in the development of the histamine $\mathrm{H} 2$-receptor antagonist, cimetidine. J. Med. Chem. 1977;20 (7):901-6.

8. Walter LA. German Patent. 1969;1: 905, 353; Chem. Abstr., 1970; 72, 317904.

9. Almansa C, Alfón J, de Arriba AF , Cavalcanti FL, Escamilla I, Gómez LA, Miralles A, Soliva R, Bartrolí J, Carceller E, Merlos M, GarcíaRafanell J. Synthesis and Structure-Activity Relationship of a New Series of COX-2 Selective Inhibitors: 1,5-Diarylimidazoles, J. Med. Chem. 2003;46 (16):3463-75.

10. Liu $H$, Kerdesky FA, Black LA, Fitzgerald $M$, Henry R, Ebenshade TA, Hancock AA, Bennani YL. An efficient multigram synthesis of the potent histamine H3 antagonist GT-2331 and the reassessment of the absolute configuration. J. Org. Chem. 2004;69(1):192-4.

11. Nallan $L$, Bauer $K D$, Bendale $P$, Rivas K, Yokoyama K, Hornéy CP, Pendyala PR, Floyd $D$, Lombardo LJ, Williams DK, Hamilton A, Sebti S, Windsor WT, Weber PC, Buckner FS, Chakrabarti D, Gelb MH, Voorhis WCV. Protein Farnesyltransferase Inhibitors Exhibit Potent Antimalarial Activity. J. Med. Chem. 2005;48(11):3704-13.

12. Berezin $M$, Achilefu $S$. Novel synthon for incorporating 1,3-dimethyl-imidazolium group into molecular architecture. Tetrahedron Letters. 2007;48(7):1195-9.

13. Davis Jr JH, Forrester KJ, Merrigan T. Novel organic ionic liquids (OILs) incorporating cations derived from the antifungal drug miconazole. Tetrahedron Letters. 1998;39(49):8955-8.

14. Hu B, Malamas M, Ellingboe J, Largis E, Han S, Mulvey R, Tillett J. New oxadiazolidinedione derivatives as potent and selective human $\beta_{3}$ agonists. Bioorganic \& Medicinal Chemistry Letters. 2001;11(8): 9814.

15. Demberelnyamba D, Kim K-S, Choi S, Park S-Y, Lee H, Kim C-J, Yoo I-D. Synthesis and antimicrobial properties of imidazolium and pyrrolidinonium salts. Bioorganic \& Medicinal Chemistry. 2004;12(5):853-7.

16. Ourth DD. Antiviral activity against human immunodeficiency virus-1 in vitro by myristoylated-peptide from Heliothis virescens. Biochemical and Biophysical Research Communications. 2004;320(1):190-6.

17. Orhan E, Garci A, Tina R, Saudani M, Dyson PJ, Therrien B. Cytotoxic double arene ruthenium metalla-cycles that overcome cisplatin resistance. Journal of Organometallic Chemistry, 2016;803: 39-44.

18. Orhan E, Garci A, Riedel T, Dyson PJ, Therrien B. Cytotoxicity of arene ruthenium metalla-rectangles incorporating bispyridyl diimide linkers. Journal of Organometallic Chemistry, 2016; 815-816: 53-8.

19. Zabielska-Matejuk J. Antifungal properties of new quaternary ammonium compounds in relation to their surface activity. Wood Sci Technol. 2005;39(3):235-43.

20. Reiter LA. Synthesis of 4(5)-acyl-, 1substituted 5-acyl- and 1-substituted 4-acyl$1 \mathrm{H}$-imidazoles from 4-aminoisoxazoles. J. Org. Chem. 1987;52(13):2714-26.

21. Koch P, Ansideri F. 2-Alkylsulfanyl-4(5)aryl-5(4)-heteroarylimidazoles: An Overview on synthetic Strategies and Biological Activity. Arch. Pharm. Chem. Life Sci. 2017;350(12): e1700258.

22. Beyer C, Wagenknecht H-A. Synthesis of Spiropyrans As Building Blocks for Molecular Switches and Dyads. J. Org. Chem. $2010 ; 75(8): 2752-5$.

23. Küçükbay $H$, Durmaz R, Orhan E, Günal $S$. Synthesis, antibacterial and antifungal activities of electron-rich olefins derived 
Orhan E, Kose M, Alkan D, Öztürk L. JOTCSA. 2019; 6(3): 373-382.

RESEARCH ARTICLE

benzimidazole compounds. Il Farmaco. $2003 ; 58(6): 431-7$.

24. Akkurt $M$, Öztürk $S$, Küçükbay $H$, Orhan $E$, Büyükgüngör $O$. 1-Ethyl-3-(2-phenylethyl) benzimidazole-2-selone. Acta Crystallographica Section E: Structure Reports Online. 2004;60(7):01263-01265.

25. Akkurt M, Yıldırım SO, Orhan E, Küçükbay $\mathrm{H}$, Büyükgüngör $\mathrm{O}$. 1-Methoxyethyl-5nitrobenzimidazole. Acta Crystallographica Section E: Structure Reports Online. 2005;61(9):02804-5.

26. Yıldırım SO, Akkurt $M$, Küçükbay $H$, Orhan $\mathrm{E}$, Büyükgüngör $O$. 6-Nitro-1-(2phenylethyl) $1 \mathrm{H}$-benzimidazole. Acta Crystallographica Section E: Structure Reports Online. 2005;61(7):02038-9.

27. Küçükbay H, Günal S, Orhan E, Durmaz R. Synthesis and Antimicrobial Activities of Some Transition Metal Benzimidazole Complexes. Asian Journal of Chemistry. 2010;22(9):7376.

28. Abdel-Magid AF, Carson KG, Harris BD, Maryanoff CA, Shah RD. Reductive Amination of Aldehydes and Ketones with Sodium Triacetoxyborohydride. Studies on Direct and Indirect Reductive Amination Procedures. J. Org. Chem. 1996;61(11):3849-62.

29. Gwaltney SL, O'Connor SJ, Nelson LTJ, Sullivan GM, Imade $H$, Wang W, Hasvold $L$, $\mathrm{Li}$ Q, Cohen J, Gu W-Z, Tahir SK, Bauch J, Marsh K, Ng S-C, Frost DJ, Zhang H, Muchmore S, Jakob CG, Stoll V, Hutchins C, Rosenberg SH, Hing. Aryl tetrahydropyridine inhibitors of farnesyltransferase: bioavailable analogues with improved cellular potency.
Bioorganic \& Medicinal Chemistry Letters. 2003;13:1363- 6 .

30. Pınar Ş, Akkurt $M$, Küçükbay $H$, Orhan $E$, Büyükgüngör $O$. Bis[1-(but-2-enyl)-5-nitro$1 \mathrm{H}$ - benzimidazole- ${ }_{k} \mathrm{~N}^{3}$ ]dichlorocobalt(II), Acta Crystallographica Section E: Structure Reports Online. 2006;62(7):m1663-5.

31. Akkurt $M$, Karaca $S$, Küçükbay $H$, Orhan $E$, Büyükgüngör $\quad 0$. 1-Benzyl-3-(2phenethyl)benzimidazolium bromide monohydrate, Acta Crystallographica Section E: Structure Reports Online. 2005;61(8):02452-4.

32. Akkurt $M$, Karaca $S$, Küçükbay $H$, Orhan $E$, Büyükgüngör $\quad 0$. Dichlorobis[1-(2ethoxyethyl)-1H-benzimidazole- ${ }_{k} \mathrm{~N}^{3}$ ]nickel(II), Acta Crystallographica Section E: Structure Online. 2004;61(1):m41-3.

33. Hubball W, Pyman FL. Glyoxaline-4(5)formaldehyde. Journal of the Chemical Society, 1928; 21-32.

34. Reiter LA. Synthesis of 4(5)-Acyl-, 1Substituted 5-Acyl-, and 1-Substituted 4-Acyl$1 \mathrm{H}$ - imidazoles from 4-Aminoisoxazoles. J. Org. Chem., 1987; 52(13): 2714-26.

35. Gilbert JG, Addison AW, Palaniandavar M and Butcher RJ. Synthesis of Some Benzimidazole-, Benzothiazole- and Pyridine Derived Chelating Agents. Journal of Heterocyclic Chemistry, 2002;39(2):399-404. 